\title{
Novel Divavirus (the family Betaflexiviridae) and Mitovirus (the family Narnaviridae) species identified in basil (Ocimum basilicum)
}

\author{
C. J. GOH${ }^{1}$, D. PARK ${ }^{1}$, H. KIM ${ }^{1}$, F. SEBASTIANI ${ }^{2}$, Y. HAHN ${ }^{*}$
}

\begin{abstract}
${ }^{1}$ Department of Life Science, Research Center for Biomolecules and Biosystems, Chung-Ang University, Seoul 06974, South Korea; ${ }^{2}$ Institute for Sustainable Plant Protection, Department of Biology, Agriculture and Food Sciences, The National Research Council of Italy, Sesto Fiorentino, Italy
\end{abstract}

\begin{abstract}
Summary. - Transcriptome data obtained from a plant sample often contain a large number of reads that are derived from associated RNA virus genomes that were co-isolated during RNA preparation. These virusderived reads can be assembled into a novel plant RNA genome sequence. Here, a basil (Ocimum basilicum) transcriptome dataset was analyzed to identify two new RNA viruses, which were named Ocimum basilicum RNA virus 1 (ObRV1) and Ocimum basilicum RNA virus 2 (ObRV2). A phylogenetic analysis of the ObRV1 RNA-dependent RNA polymerase (RdRp) motif indicated that ObRV1 is a novel species of the genus Divavirus of the family Betaflexiviridae. ObRV1 is the fourth divavirus species to be identified. The ObRV2 RdRp motif showed sequence similarity to viruses of the genus Mitovirus of the family Narnaviridae, which infect fungal mitochondria. Although most of the known mitoviruses do not produce a functional RdRp using the plant mitochondrial genetic code, the ObRV2 encodes a full-length RdRp using both the fungal and plant mitochondrial genetic codes.
\end{abstract}

Keywords: basil; Ocimum basilicum RNA virus 1; Ocimum basilicum RNA virus 2; Divavirus; Mitovirus

\section{Introduction}

Basil (Ocimum basilicum L.) is a popular herb that belongs to the genus Ocimum of the family Lamiaceae. It is widely cultivated in Asia, the Mediterranean region, and the United States of America for commercial and industrial purposes (Dudai et al., 2002; Suppakul et al., 2003; Chiang et al., 2005). Basil is also used as a medicinal, antiviral, antibacterial, and antimicrobial agent, with its essential oils being known to have many beneficial compounds, such as monoterpenoids, which act against pathogens such as virus, bacteria, and fungi (Edris and Farrag, 2003; Suppakul et al., 2003; Chiang et al., 2005).

*Corresponding author. E-mail: hahny@cau.ac.kr; phone: +82-2820-5812.

Abbreviations: ObRV1 = Ocimum basilicum virus 1; ObRV2 = Ocimum basilicum virus $2 ; \mathrm{ORF}=$ open reading frame; $\mathrm{RdRp}=\mathrm{RNA}$ dependent RNA polymerase; SRA = Sequence Read Archive
Transcriptome analyses of basil have been conducted to investigate its genetic features, such as the genes involved in secondary metabolism and production of unique essential oils (Rastogi et al., 2014; Torre et al., 2016). The plant transcriptome data often contain sequences derived from RNA viruses, which can be identified to be novel plant RNA viruses (Nouri et al., 2016; Visser et al., 2016; Park and Hahn, 2017a,b). In this study, a previously reported transcriptome dataset collected from red and green morphs of sweet basil was analyzed and potential sequences of two novel RNA viruses, a divavirus and a mitovirus, were identified (Torre et al., 2016).

Currently, only three species are reported in the genus Divavirus of the family Betaflexiviridae (Wylie and Jones, 2011; Wylie et al., 2013). The Betaflexviridae viruses have a linear, single-stranded, positive-sense RNA genomic segment $6.5-9.0 \mathrm{~kb}$ in size, which encodes $2-6$ proteins, including the RNA-dependent RNA polymerase (RdRp) and several other proteins depending on the genus (Adams, 2012; Igori et al., 2016). 
Table 1. Summary of RNA viruses identified in this study

\begin{tabular}{llllll}
\hline Acronym & Full name & Acc. No. & Length (nt) & ORF & Position \\
\hline ObRV1 & Ocimum basilicum RNA virus 1 & MF196913 & 6930 & Replicase/Coat protein & $44-6721$ \\
& & & & Movement protein & 2255 \\
ObRV2 & Ocimum basilicum RNA virus 2 & MF196914 & 2784 & Replicase & 389 \\
\hline
\end{tabular}

Viruses of the family Narnaviridae, to which the genus Mitovirus belongs, have an unencapsidated, linear, singlestranded, positive-sense RNA genome $2.5-2.9 \mathrm{~kb}$ in size, which encodes a single open reading frame (ORF) for the replicase containing the RdRp motif(Hillman and Cai, 2013). Mitoviruses replicate in the cytosol or mitochondria of infected fungi and have been mainly isolated from plant-pathogenic fungi (Ghabrial and Suzuki, 2009; Xie and Ghabrial, 2012).

\section{Materials and Methods}

The previously reported basil transcriptome dataset (a total of 13 gigabase pairs), which was isolated from red and green sweet basils, was analyzed in this study (Torre et al., 2016). The transcriptome data is available in the Sequence Read Archive (SRA) of the National Center for Biotechnology Information (NCBI) under the accession number SRA313233. Sickle program (version 1.33; https://github.com/najoshi/sickle) was used to collect high-quality reads with the option “-q 30 -1 55." The SPAdes Genome Assembler (version 3.10.1) was used to assemble the RNA-seq reads into contigs (Bankevich et al., 2012).

The RdRp motif sequences of known RNA viruses were retrieved from the Pfam database (release 30.0; http://pfam.xfam.org). A total of 345 non-redundant RdRp motif sequences were collected from 19 RdRp families: their accession numbers are PF00602, PF00603, PF00604, PF00680, PF00946, PF00972, PF00978, PF00998, PF02123, PF03431, PF04196, PF04197, PF05788, PF05919, PF07925, PF08467, PF08716, PF08717, and PF12426.

The assembled basil transcript contigs were compared with the Pfam-derived RdRp sequences, using BLAST (Altschul et al., 1990) with the parameter “-evalue e-5." Matched contigs 1000 bp or longer were selected. Annotation of contigs and identification of closely related viruses were carried out by BLAST searches of all viral genomes and proteins at the NCBI website (https://www.ncbi. nlm.nih.gov/BLAST). The basil RNA-seq reads were mapped to the viral contigs, using BWA, and variants were called using Samtools/ Bcftools (Li and Durbin, 2009; Li, 2011).

For phylogenetic analysis, the RdRp motif-containing sequences were multiply aligned using the MUSCLE program (Edgar, 2004). The aligned region spanning the core RdRp motif defined by a Pfam analysis was extracted and subjected to phylogenetic analysis. A phylogenetic tree was constructed by the neighbor-joining method implemented in the ClustalW2 software (version 2.1) (Larkin et al., 2007).

\section{Results and Discussion}

Genome sequences of two new viruses (Table 1) were identified by analysis of the basil transcriptome data (SRA accession number SRA313233) (Torre et al., 2016). One viral contig, named Ocimum basilicum RNA virus 1 (ObRV1), was most similar to those of divaviruses (Table 2) and considered a novel member of the genus Divavirus. The other contig, named Ocimum basilicum RNA virus 2 (ObRV2), showed sequence similarity to those of mitoviruses (Table 2), suggesting that it belongs to the genus Mitovirus.

\section{Ocimum basilicum RNA virus 1 (ObRV1)}

The first of the two viral contigs discovered in the basil transcriptome was named Ocimum basilicum RNA virus 1 (ObRV1) and showed sequence similarity to those of plant RNA viruses of the genus Divavirus of the family Betaflexiviridae. There were sequence variations at 33 positions when the basil RNA-seq reads mapped to the ObRV1 genome were analyzed, indicating that the contig is a composite sequence derived from at least two closely related viruses (Supplementary Table S1).

The ObRV1 RNA genome is 6,930 base pairs (bp) long and predicted to have two overlapping ORFs. ORF1 encodes a 2,255-amino acid (aa)-long RdRp motif-containing protein and ORF2 a 389-aa-long movement protein (Table 1). A domain analysis using Pfam showed that the ObRV1 ORF1 protein contains four known domains: viral methyltransferase (PF01660) at aa 43-357, viral RNA helicase (PF01443) at aa $858-1,119, \operatorname{RdRp}(\mathrm{PF} 00978)$ at aa $1,255-1,653$, and trichovirus coat protein (PF05892) at aa 2,039-2,223. These genome and domain organizations are the shared features of viruses in the genera Divavirus and Capillovirus (Jelkmann, 1995; Wylie and Jones, 2011).

The ObRV1 RdRp showed 30-60\% aa sequence identities with RdRps of the viruses that belong to the family Betaflexiviridae (Table 2). Among them, Hardenbergia virus A (HarVA), Diuris virus A (DiVA), and Diuris virus B (DiVB) were the top three similar viruses with aa sequence identities of $50-60 \%$. These three viruses are species in the genus Divavirus, suggesting that ObRV1 is a new divavirus.

A phylogenetic analysis using multiply aligned RdRp motif sequences confirmed that ObRV1 is a new species of the genus Divavirus (Supplementary Fig. S1 and Fig. 1a). 
Table 2. Identities among the RdRp sequences of ObRV1, ObRV2, and their respective related viruses

\begin{tabular}{|c|c|c|c|c|}
\hline & Acronym & Full name & Acc. No. ${ }^{a}$ & Sequence identity ${ }^{\mathrm{b}}$ \\
\hline \multirow[t]{17}{*}{ ObRV1 } & HarVA & Hardenbergia virus A & YP_004376201.1 & $1341 / 2237(60 \%)$ \\
\hline & DiVA & Diuris virus A & YP_006905850.1 & $1243 / 2248(55 \%)$ \\
\hline & DiVB & Diuris virus B & YP_006905848.1 & $1196 / 2256(53 \%)$ \\
\hline & CVA & Cherry virus A & ANE06570.1 & $357 / 949(38 \%)$ \\
\hline & CVA & Cherry virus A & APG53775.1 & $331 / 848(39 \%)$ \\
\hline & PCMV & Peach chlorotic mottle virus & YP_001497153.1 & $336 / 928(36 \%)$ \\
\hline & ApLV & Apricot latent virus & ADT91605.1 & $334 / 910(37 \%)$ \\
\hline & $\mathrm{NeLV}$ & Nerine latent virus & YP_009174681.1 & $335 / 1030(33 \%)$ \\
\hline & NSV & Narcissus symptomless virus & YP_842438.1 & $336 / 1030(33 \%)$ \\
\hline & CTLaV & Cherry twisted leaf associated virus & AHJ80270.1 & $326 / 840(39 \%)$ \\
\hline & CTLaV & Cherry twisted leaf associated virus & AHJ80314.1 & $326 / 859(38 \%)$ \\
\hline & CNRMV & Cherry necrotic rusty mottle virus & ALP45953.1 & $338 / 909(37 \%)$ \\
\hline & CRMaV & Cherry rusty mottle associated virus & AHA59466.2 & $323 / 846(38 \%)$ \\
\hline & $\mathrm{CRMaV}$ & Cherry rusty mottle associated virus & AHJ80324.1 & $317 / 839(38 \%)$ \\
\hline & CRMaV & Cherry rusty mottle associated virus & AKN20442.1 & $347 / 971(36 \%)$ \\
\hline & CGRMV & Cherry green ring mottle virus & AFU54620.1 & $318 / 825(39 \%)$ \\
\hline & BanMMV & Banana mild mosaic virus & NP_112029.1 & $321 / 870(37 \%)$ \\
\hline \multirow[t]{26}{*}{ ObRV2 } & BcMV1 & Botrytis cinerea mitovirus 1 & CEZ26300.1 & $165 / 506(33 \%)$ \\
\hline & FpMV4 & Fusarium poae mitovirus 4 & YP_009272901.1 & $104 / 224(46 \%)$ \\
\hline & OMV3a & Ophiostoma mitovirus $3 \mathrm{a}$ & NP_660176.1 & $101 / 241(42 \%)$ \\
\hline & SsMV3 & Sclerotinia sclerotiorum mitovirus 3 & YP_009182164.1 & $110 / 283(39 \%)$ \\
\hline & MpMV3 & Macrophomina phaseolina mitovirus 3 & AMM45292.1 & $100 / 273(37 \%)$ \\
\hline & RsMV-17 & Rhizoctonia solani mitovirus 17 & ANR02693.1 & $91 / 230(40 \%)$ \\
\hline & RsMV-15 & Rhizoctonia solani mitovirus 15 & ALD89120.1 & $100 / 276(36 \%)$ \\
\hline & RsMV-14 & Rhizoctonia solani mitovirus 14 & ALD89119.1 & $102 / 297(34 \%)$ \\
\hline & HetMV1 & Heterobasidion mitovirus 1 & AIF33766.2 & $158 / 547(29 \%)$ \\
\hline & $\mathrm{COV}$ & Clitocybe odora virus & YP_005352912.1 & $174 / 577(30 \%)$ \\
\hline & BcMV3 & Botrytis cinerea mitovirus 3 & YP_009182161.1 & $113 / 304(37 \%)$ \\
\hline & FpMV3 & Fusarium poae mitovirus 3 & YP_009272900.1 & $87 / 219(40 \%)$ \\
\hline & SlaMV5 & Soybean leaf-associated mitovirus 5 & ALM62240.1 & $87 / 233(37 \%)$ \\
\hline & RsMV-19 & Rhizoctonia solani mitovirus 19 & ANR02690.1 & $87 / 221(39 \%)$ \\
\hline & BsMV1 & Buergenerula spartinae mitovirus 1 & AHY03257.1 & $91 / 242(38 \%)$ \\
\hline & CpMV1 & Cryphonectria parasitica mitovirus 1-NB631 & NP_660174.1 & $79 / 216(37 \%)$ \\
\hline & RcMV & Rhizoctonia cerealis mitovirus & AIT71973.1 & $89 / 241(37 \%)$ \\
\hline & SsMV15 & Sclerotinia sclerotiorum mitovirus 15 & AHF48631.1 & $81 / 208(39 \%)$ \\
\hline & HfMV1 & Hymenoscyphus fraxineus mitovirus 1 & AIU44705.1 & $81 / 208(39 \%)$ \\
\hline & SsMV16 & Sclerotinia sclerotiorum mitovirus 16 & AHF48632.1 & $89 / 240(37 \%)$ \\
\hline & SsMV2 & Sclerotinia sclerotiorum mitovirus 2 & AHX84129.1 & $88 / 232(38 \%)$ \\
\hline & SlaMV3 & Soybean leaf-associated mitovirus 3 & ALM62243.1 & $76 / 203(37 \%)$ \\
\hline & OMV5 & Ophiostoma mitovirus 5 & NP_660180.1 & $82 / 213(38 \%)$ \\
\hline & SlaMV2 & Soybean leaf-associated mitovirus 2 & ALM62242.1 & $78 / 209(37 \%)$ \\
\hline & FgMV1 & Fusarium globosum mitovirus 1 & YP_009126872.1 & $110 / 367(30 \%)$ \\
\hline & TbMV & Thielaviopsis basicola mitovirus & AAZ99833.1 & $127 / 435(29 \%)$ \\
\hline
\end{tabular}

${ }^{a}$ Acc. No. for the RdRp motif-containing protein sequence. ${ }^{b}$ Amino acid sequence identities in a format of "identical residues/aligned length (\% identity)."

The ObRV1 was clustered with the three known divaviruses, with HarVA being the closest species. Currently, there are three known species of the genus Divavirus (Wylie and Jones, 2011; Wylie et al., 2013); ObRV1 is the fourth divavirus species to be reported.
Ocimum basilicum RNA virus 2 (ObRV2)

The second viral contig was named Ocimum basilicum RNA virus 2 (ObRV2) and showed sequence similarity to those of viruses of the genus Mitovirus of the family Nar- 
(a) ObRV1

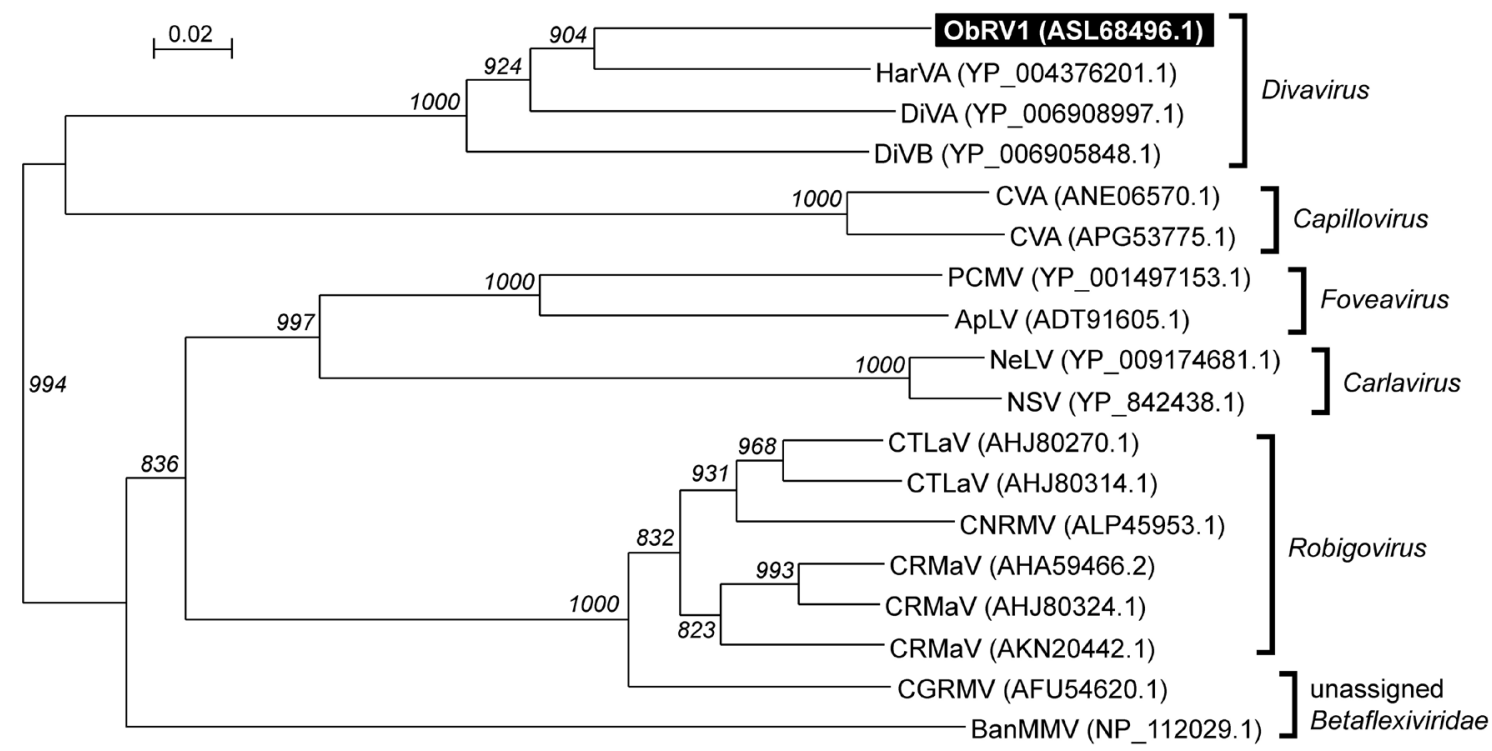

(b) ObRV2

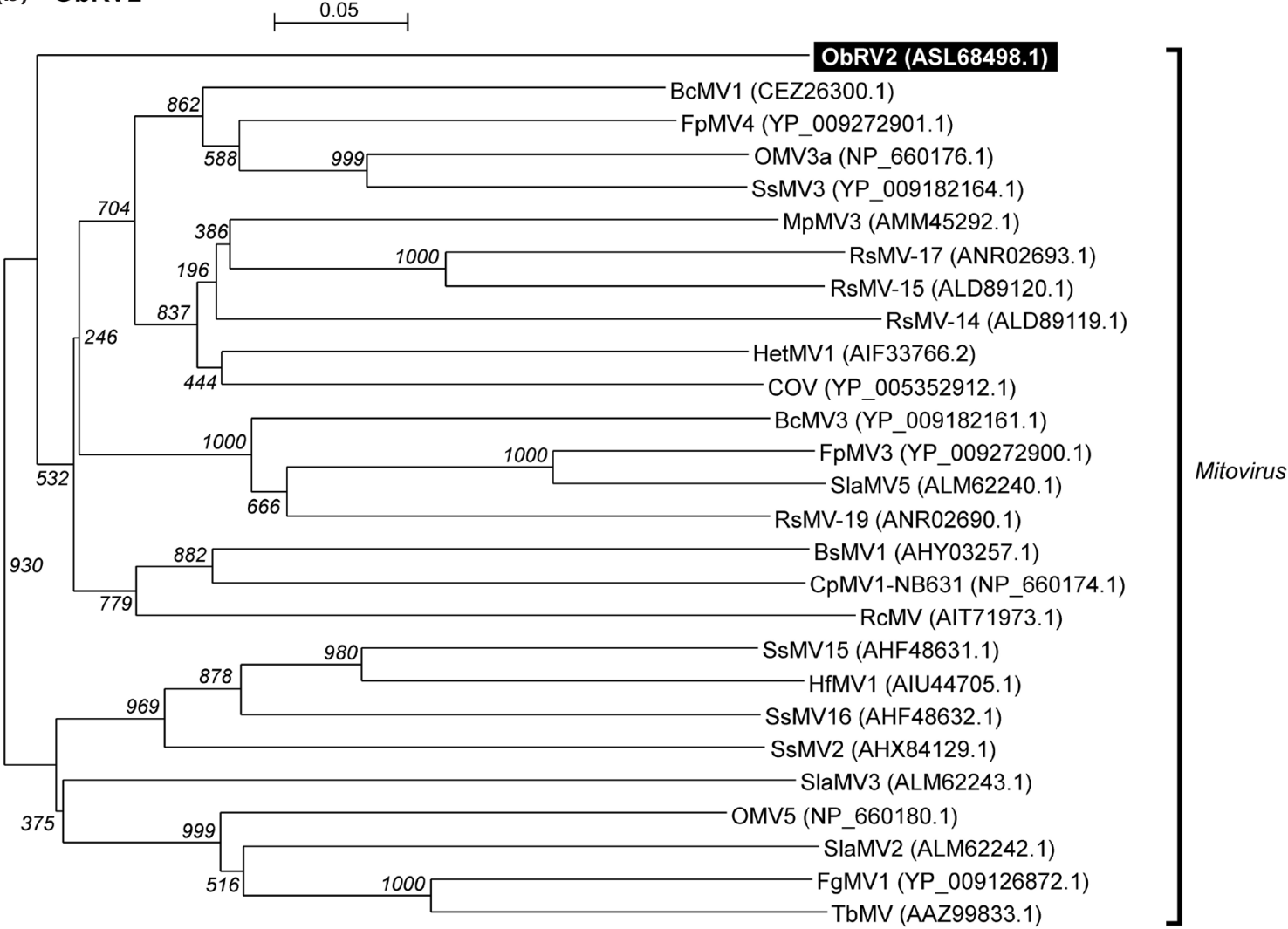

Fig. 1

Phylogenetic analysis of newly identified basil RNA viruses

Phylogenetic trees constructed based on the amino acid sequences of the RdRp motifs of (a) ObRV1 and (b) ObRV2 are presented. The bootstrap percentages calculated from 1,000 bootstrap replicates are shown at the nodes. See Table 2 for the full names of the viruses and Supplementary Figs. S1 (ObRV1) and S2 (ObRV2) for the multiple sequence alignments of the amino acid sequences of the RdRp motifs. 
naviridae. Given that mitoviruses generally infect fungi, it was uncertain whether this mitovirus genome was isolated directly from basil cells or fungal cells that infected basil (Hillman and Cai, 2013).

The ObRV2 genome is 2,784-bp long and predicted to have a single ORF encoding a 760-aa-long protein when it was translated using both the fungal mitochondrial and plant (standard) genetic codes (Table 1). A Pfam analysis indicated that the ORF contains a mitovirus-type RdRp motif (PF05919) at aa 268-579. There were sequence variations at 61 positions, indicating that the ObRV2 genome contig is also a composite sequence derived from two or more clones (Supplementary Table S2).

The ObRV2 RdRp motif-containing protein showed about $30-40 \%$ similarity to those of other mitoviruses (Table 2). A phylogenetic analysis based on a multiple sequence alignment of the RdRp domain sequences placed ObRV2 as a distinct clade within the genus Mitovirus (Fig. $1 \mathrm{~b}$ and Supplementary Fig. S2).

Most of the fungal mitoviruses replicate within the mitochondria of fungal cells and are unable to produce functional RdRps in plant cells because the genetic codes of fungal mitochondria and plants are different. For instance, the UGA codon, which is a stop codon in the standard genetic code, encodes for tryptophan in fungal mitochondria (Nibert, 2017). However, the ObRV2 ORF encodes a full-length RdRp using the plant nuclear and mitochondrial genetic codes, suggesting that ObRV2 may be able to replicate in both fungal and plant cells.

Interestingly, there are mitovirus-derived sequences in many plant nuclear and mitochondrial genomes, some of which are expressed as plant genes (Bruenn et al., 2015; Xu et al., 2015). Because the ObRV2 sequence was found in a plant transcriptome and encodes a full-length protein, it could also be derived from a mitovirus-like gene integrated in the basil nuclear or mitochondrial genome. However, most plant mitovirus-like genes are derived from the RdRp domain and are relatively shorter than those encoding the mitovirus RdRps; plant mitovirus-like genes encode for proteins about 500-aa long or shorter, while the mitovirus RdRps are 700-aa long or longer. The ObRV2 RdRp is 760-aa long. Therefore, it is highly likely that the ObRV2 sequence represents a mitovirus that infects the basil or a basil-associated fungus.

In conclusion, basil transcriptome data were analyzed to identify viral genome sequences representing two novel viral species of the genera Divavirus and Mitovirus. The method used in this study can be applied to other plant transcriptome data to discover plant viral genome sequences co-isolated with their host RNAs.

Acknowledgment. This research was supported by the National Research Foundation of Korea funded by the Korean Government (2017R1A1B4005866).
Supplementary information is available in the online version of the paper.

\section{References}

Adams MJ, Candresse T, Hammond J, Kreuze JF, Martelli GP, Namba S, Pearson MN, Ryu KH, Saldarelli P, Yoshikawa N (2012): Family Betaflexiviridae. In King AMQ, Adams MJ, Carstens EB, Lefkowitz EJ (Eds): Virus Taxonomy. Classification and nomenclature of viruses. Ninth report of the International Committee on Taxonomy of Viruses. Elsevier Academic Press, San Diego, CA, pp. 920-941.

Altschul SF, Gish W, Miller W, Myers EW, Lipman DJ (1990): Basic local alignment search tool. J. Mol. Biol. 215, 403-410. https://doi.org/10.1016/S0022-2836(05)80360-2

Bankevich A, Nurk S, Antipov D, Gurevich AA, Dvorkin M, Kulikov AS, Lesin VM, Nikolenko SI, Pham S, Prjibelski AD, Pyshkin AV, Sirotkin AV, Vyahhi N, Tesler G, Alekseyev MA, Pevzner PA (2012): SPAdes: a new genome assembly algorithm and its applications to single-cell sequencing. J. Comput. Biol. 19, 455-477. https://doi.org/10.1089/ cmb.2012.0021

Bruenn JA, Warner BE, Yerramsetty P (2015): Widespread mitovirus sequences in plant genomes. PeerJ 3, e876. https:// doi.org/10.7717/peerj.876

Chiang LC, Ng LT, Cheng PW, Chiang W, Lin CC (2005): Antiviral activities of extracts and selected pure constituents of Ocimum basilicum. Clin. Exp. Pharmacol. Physiol. 32, 811816. https://doi.org/10.1111/j.1440-1681.2005.04270.x

Dudai N, Chaimovitsh D, Reuveni R, Ravid U, Larkov O, Putievsky E (2002): Breeding of sweet basil (Ocimum basilicum) resistant to Fusarium wilt caused by Fusarium oxysporum f.sp. basilicum. J. Herbs Spices Med. Plants 9, 45-51. https://doi.org/10.1300/J044v09n02 07

Edgar RC (2004): MUSCLE: multiple sequence alignment with high accuracy and high throughput. Nucleic Acids Res. 32, 1792-1797. https://doi.org/10.1093/nar/gkh340

Edris AE, Farrag ES (2003): Antifungal activity of peppermint and sweet basil essential oils and their major aroma constituents on some plant pathogenic fungi from the vapor phase. Nahrung 47, 117-121. https://doi.org/10.1002/ food.200390021

Ghabrial SA, Suzuki N (2009): Viruses of plant pathogenic fungi. Annu. Rev. Phytopathol. 47, 353-384. https://doi. org/10.1146/annurev-phyto-080508-081932

Hillman BI, Cai G (2013): The family Narnaviridae: simplest of RNA viruses. Adv. Virus Res. 86, 149-176. https://doi. org/10.1016/B978-0-12-394315-6.00006-4

Igori D, Lim S, Zhao F, Baek D, Park JM, Cho HS, Kim HS, Kwon SY, Moon JS (2016): The complete sequence and genome organization of Ligustrum virus A, a novel carlavirus. Arch. Virol. 161, 3593-3596. https://doi.org/10.1007/ s00705-016-3054-x

Jelkmann W (1995): Cherry virus A: cDNA cloning of dsRNA, nucleotide sequence analysis and serology reveal a new plant capillovirus in sweet cherry. J. Gen. Virol. 76 (Pt 8), 2015-2024. https://doi.org/10.1099/0022-1317-76-8-2015 
Larkin MA, Blackshields G, Brown NP, Chenna R, McGettigan PA, McWilliam H, Valentin F, Wallace IM, Wilm A, Lopez R, Thompson JD, Gibson TJ, Higgins DG (2007): Clustal W and Clustal X version 2.0. Bioinformatics 23, 2947-2948. https://doi.org/10.1093/bioinformatics/btm404

Li H (2011): A statistical framework for SNP calling, mutation discovery, association mapping and population genetical parameter estimation from sequencing data. Bioinformatics 27, 2987-2993. https://doi.org/10.1093/bioinformatics/btr509

Li H, Durbin R (2009): Fast and accurate short read alignment with Burrows-Wheeler transform. Bioinformatics 25, 17541760. https://doi.org/10.1093/bioinformatics/btp324

Nibert ML (2017): Mitovirus UGA(Trp) codon usage parallels that of host mitochondria. Virology 507, 96-100. https://doi. org/10.1016/j.virol.2017.04.010

Nouri S, Salem N, Falk BW (2016): Complete genome sequence of Diaphorina citri-associated C virus, a novel putative RNA virus of the Asian citrus psyllid, Diaphorina citri. Genome Announc. 4, e00639-00616. https://doi.org/10.1128/ genomeA.00639-16

Park D, Hahn Y (2017a): Genome sequence of Spinach cryptic virus 1 , a new member of the genus Alphapartitivirus (family Partitiviridae), identified in spinach. J. Microbiol. Biotechnol. 27, 834-837. https://doi.org/10.4014/jmb.1611.11026

Park D, Hahn Y (2017b): Genome sequences of Spinach deltapartitivirus 1, Spinach amalgavirus 1, and Spinach latent virus identified in spinach transcriptome. J. Microbiol. Biotechnol. 27, 1324-1330. https://doi.org/10.4014/ jmb.1703.03043

Rastogi S, Meena S, Bhattacharya A, Ghosh S, Shukla RK, Sangwan NS, Lal RK, Gupta MM, Lavania UC, Gupta V, Nagegowda DA, Shasany AK (2014): De novo sequencing and com- parative analysis of holy and sweet basil transcriptomes. BMC Genomics 15, 588. https://doi.org/10.1186/14712164-15-588

Suppakul P, Miltz J, Sonneveld K, Bigger SW (2003): Antimicrobial properties of basil and its possible application in food packaging. J. Agric. Food Chem. 51, 3197-3207. https:// doi.org/10.1021/jf021038t

Torre S, Tattini M, Brunetti C, Guidi L, Gori A, Marzano C, Landi M, Sebastiani F (2016): De novo assembly and comparative transcriptome analyses of red and green morphs of sweet basil grown in full sunlight. PLOS ONE 11, e0160370. https://doi.org/10.1371/journal.pone.0160370

Visser M, Bester R, Burger JT, Maree HJ (2016): Next-generation sequencing for virus detection: covering all the bases. Virol. J. 13, 85. https://doi.org/10.1186/s12985-016-0539-x

Wylie S, Jones M (2011): Hardenbergia virus A, a novel member of the family Betaflexiviridae from a wild legume in Southwest Australia. Arch. Virol. 156, 1245-1250. https://doi. org/10.1007/s00705-011-0963-6

Wylie SJ, Li H, Dixon KW, Richards H, Jones MG (2013): Exotic and indigenous viruses infect wild populations and captive collections of temperate terrestrial orchids (Diuris species) in Australia. Virus Res. 171, 22-32. https://doi. org/10.1016/j.virusres.2012.10.003

Xie J, Ghabrial SA (2012): Molecular characterizations of two mitoviruses co-infecting a hypovirulent isolate of the plant pathogenic fungus Sclerotinia sclerotiorum. Virology 428, 77-85. https://doi.org/10.1016/j.virol.2012.03.015

Xu Z, Wu S, Liu L, Cheng J, Fu Y, Jiang D, Xie J (2015): A mitovirus related to plant mitochondrial gene confers hypovirulence on the phytopathogenic fungus Sclerotinia sclerotiorum. Virus Res. 197, 127-136. https://doi.org/10.1016/j. virusres.2014.12.023 


\title{
Supplementary information
}

\section{Novel Divavirus (the family Betaflexiviridae) and Mitovirus (the family Narnaviridae) species identified in basil (Ocimum basilicum)}

\author{
C. J. GOH${ }^{1}$, D. PARK ${ }^{1}$, H. KIM ${ }^{1}$, F. SEBASTIANI ${ }^{2}$, Y. HAHN ${ }^{*}$
}

${ }^{1}$ Department of Life Science, Research Center for Biomolecules and Biosystems, Chung-Ang University, Seoul 06974, South Korea;

${ }^{2}$ Institute for Sustainable Plant Protection, Department of Biology, Agriculture and Food Sciences, The National Research Council of Italy, Sesto Fiorentino, Italy

Received October 3, 2017; revised December 19, 2017; accepted July 10, 2018

Supplementary Table S1. Sequence variation of ObRV1

\begin{tabular}{|c|c|c|c|c|c|c|c|}
\hline Position & Con $^{\mathrm{a}}$ & $\mathbf{A l t}^{\mathrm{b}}$ & Quality ${ }^{c}$ & Con \# & Alt \# & Con \% & Alt $\%$ \\
\hline 274 & A & G & 222 & 2212 & 2792 & 44.2 & 55.8 \\
\hline 535 & G & A & 222 & 7568 & 4917 & 60.6 & 39.4 \\
\hline 709 & $\mathrm{~T}$ & $\mathrm{C}$ & 222 & 6593 & 4802 & 57.9 & 42.1 \\
\hline 871 & G & A & 222 & 6262 & 5003 & 55.6 & 44.4 \\
\hline 904 & A & G & 222 & 5955 & 4258 & 58.3 & 41.7 \\
\hline 907 & A & $\mathrm{T}$ & 222 & 5978 & 4217 & 58.6 & 41.4 \\
\hline 1330 & $\mathrm{~T}$ & $\mathrm{C}$ & 222 & 7713 & 4836 & 61.5 & 38.5 \\
\hline 1421 & $\mathrm{~T}$ & $\mathrm{C}$ & 222 & 8349 & 5928 & 58.5 & 41.5 \\
\hline 1423 & G & $\mathrm{T}$ & 222 & 8496 & 5927 & 58.9 & 41.1 \\
\hline 1912 & G & A & 222 & 7838 & 4337 & 64.4 & 35.6 \\
\hline 2305 & $\mathrm{~T}$ & $\mathrm{C}$ & 222 & 7486 & 4512 & 62.4 & 37.6 \\
\hline 2407 & $\mathrm{C}$ & $\mathrm{T}$ & 222 & 8855 & 5501 & 61.7 & 38.3 \\
\hline 2758 & $\mathrm{~T}$ & $\mathrm{C}$ & 222 & 7397 & 4396 & 62.7 & 37.3 \\
\hline 2761 & A & G & 222 & 7580 & 4294 & 63.8 & 36.2 \\
\hline 3403 & G & A & 222 & 8320 & 6555 & 55.9 & 44.1 \\
\hline 3689 & $\mathrm{~T}$ & C & 222 & 8390 & 6545 & 56.2 & 43.8 \\
\hline 4036 & A & G & 222 & 9544 & 7299 & 56.7 & 43.3 \\
\hline 4222 & G & A & 222 & 9823 & 8396 & 53.9 & 46.1 \\
\hline 4243 & $\mathrm{~T}$ & A & 222 & 9350 & 7276 & 56.2 & 43.8 \\
\hline 4576 & A & G & 222 & 9959 & 7574 & 56.8 & 43.2 \\
\hline 4645 & $\mathrm{~T}$ & C & 222 & 10088 & 8018 & 55.7 & 44.3 \\
\hline 4978 & A & G & 222 & 11797 & 8422 & 58.3 & 41.7 \\
\hline 4984 & G & A & 222 & 12145 & 8704 & 58.3 & 41.7 \\
\hline 5130 & $\mathrm{~T}$ & C & 222 & 11593 & 8383 & 58.0 & 42.0 \\
\hline 5253 & $\mathrm{~T}$ & C & 222 & 15217 & 11009 & 58.0 & 42.0 \\
\hline 5307 & C & $\mathrm{T}$ & 222 & 15145 & 10481 & 59.1 & 40.9 \\
\hline 5343 & C & $\mathrm{T}$ & 222 & 12969 & 9216 & 58.5 & 41.5 \\
\hline 5511 & G & A & 222 & 13535 & 9896 & 57.8 & 42.2 \\
\hline 5539 & A & G & 222 & 12512 & 9866 & 55.9 & 44.1 \\
\hline 5785 & C & $\mathrm{T}$ & 222 & 15605 & 11631 & 57.3 & 42.7 \\
\hline 5905 & C & $\mathrm{T}$ & 222 & 13495 & 11168 & 54.7 & 45.3 \\
\hline 6511 & G & A & 222 & 12695 & 8850 & 58.9 & 41.1 \\
\hline 6551 & $\mathrm{C}$ & $\mathrm{T}$ & 222 & 15251 & 11238 & 57.6 & 42.4 \\
\hline
\end{tabular}

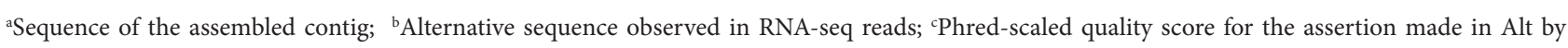
BCFtools. 
Supplementary Table S2. Sequence variation of ObRV2

\begin{tabular}{|c|c|c|c|c|c|c|c|}
\hline Position & Con $^{a}$ & $\mathrm{Alt}^{\mathrm{b}}$ & Quality $^{c}$ & Con \# & Alt \# & Con $\%$ & Alt \% \\
\hline 335 & CAA & CAAA & 183 & 21 & 18 & 53.8 & 46.2 \\
\hline 352 & A & $\mathrm{T}$ & 181 & 21 & 15 & 58.3 & 41.7 \\
\hline 355 & A & $\mathrm{T}$ & 179 & 21 & 15 & 58.3 & 41.7 \\
\hline 442 & $\mathrm{C}$ & $\mathrm{T}$ & 222 & 35 & 32 & 52.2 & 47.8 \\
\hline 445 & $\mathrm{~T}$ & $\mathrm{C}$ & 222 & 39 & 30 & 56.5 & 43.5 \\
\hline 451 & A & G & 222 & 42 & 33 & 56.0 & 44.0 \\
\hline 454 & $\mathrm{~T}$ & $\mathrm{C}$ & 222 & 47 & 35 & 57.3 & 42.7 \\
\hline 583 & $\mathrm{C}$ & $\mathrm{T}$ & 212 & 42 & 22 & 65.6 & 34.4 \\
\hline 601 & $\mathrm{~T}$ & $\mathrm{C}$ & 222 & 41 & 25 & 62.1 & 37.9 \\
\hline 676 & $\mathrm{C}$ & $\mathrm{T}$ & 222 & 39 & 30 & 56.5 & 43.5 \\
\hline 691 & $\mathrm{C}$ & $\mathrm{T}$ & 222 & 40 & 22 & 64.5 & 35.5 \\
\hline 715 & $\mathrm{C}$ & $\mathrm{T}$ & 222 & 36 & 24 & 60.0 & 40.0 \\
\hline 736 & A & G & 222 & 30 & 27 & 52.6 & 47.4 \\
\hline 763 & G & A & 222 & 38 & 27 & 58.5 & 41.5 \\
\hline 776 & $\mathrm{C}$ & G & 222 & 40 & 30 & 57.1 & 42.9 \\
\hline 835 & $\mathrm{C}$ & $\mathrm{T}$ & 222 & 31 & 26 & 54.4 & 45.6 \\
\hline 836 & G & $\mathrm{C}$ & 222 & 30 & 26 & 53.6 & 46.4 \\
\hline 889 & G & A & 222 & 45 & 52 & 46.4 & 53.6 \\
\hline 911 & $\mathrm{C}$ & A & 222 & 48 & 43 & 52.7 & 47.3 \\
\hline 912 & G & A & 222 & 47 & 43 & 52.2 & 47.8 \\
\hline 926 & A & $\mathrm{C}$ & 222 & 52 & 44 & 54.2 & 45.8 \\
\hline 940 & $\mathrm{C}$ & $\mathrm{T}$ & 222 & 55 & 39 & 58.5 & 41.5 \\
\hline 961 & $\mathrm{~T}$ & $\mathrm{C}$ & 222 & 56 & 31 & 64.4 & 35.6 \\
\hline 967 & G & A & 222 & 50 & 25 & 66.7 & 33.3 \\
\hline 1006 & $\mathrm{C}$ & G & 219 & 34 & 21 & 61.8 & 38.2 \\
\hline 1007 & A & $\mathrm{C}$ & 217 & 34 & 21 & 61.8 & 38.2 \\
\hline 1065 & $\mathrm{C}$ & G & 222 & 30 & 20 & 60.0 & 40.0 \\
\hline 1066 & $\mathrm{C}$ & $\mathrm{T}$ & 221 & 31 & 20 & 60.8 & 39.2 \\
\hline 1085 & G & A & 222 & 32 & 26 & 55.2 & 44.8 \\
\hline 1102 & $\mathrm{C}$ & $\mathrm{T}$ & 222 & 30 & 29 & 50.8 & 49.2 \\
\hline 1178 & $\mathrm{C}$ & A & 222 & 38 & 24 & 61.3 & 38.7 \\
\hline 1267 & A & $\mathrm{T}$ & 222 & 47 & 35 & 57.3 & 42.7 \\
\hline 1276 & G & A & 222 & 49 & 33 & 59.8 & 40.2 \\
\hline 1321 & A & G & 222 & 50 & 32 & 61.0 & 39.0 \\
\hline 1330 & $\mathrm{~T}$ & $\mathrm{C}$ & 222 & 49 & 36 & 57.6 & 42.4 \\
\hline 1465 & $\mathrm{~T}$ & $\mathrm{C}$ & 222 & 25 & 21 & 54.3 & 45.7 \\
\hline 1486 & $\mathrm{C}$ & $\mathrm{T}$ & 12.9425 & 45 & 6 & 88.2 & 11.8 \\
\hline 1504 & G & A & 222 & 26 & 26 & 50.0 & 50.0 \\
\hline 1510 & $\mathrm{~T}$ & $\mathrm{C}$ & 222 & 25 & 28 & 47.2 & 52.8 \\
\hline 1594 & A & $\mathrm{T}$ & 222 & 23 & 21 & 52.3 & 47.7 \\
\hline 1600 & $\mathrm{C}$ & $\mathrm{T}$ & 221 & 22 & 17 & 56.4 & 43.6 \\
\hline 1732 & $\mathrm{~T}$ & $\mathrm{C}$ & 222 & 52 & 42 & 55.3 & 44.7 \\
\hline 1775 & G & A & 172 & 48 & 40 & 54.5 & 45.5 \\
\hline 1777 & A & $\mathrm{C}$ & 157 & 49 & 40 & 55.1 & 44.9 \\
\hline 1810 & G & A & 222 & 30 & 32 & 48.4 & 51.6 \\
\hline 1837 & $\mathrm{C}$ & $\mathrm{T}$ & 222 & 34 & 31 & 52.3 & 47.7 \\
\hline 1939 & $\mathrm{~T}$ & G & 174 & 32 & 13 & 71.1 & 28.9 \\
\hline 1996 & $\mathrm{C}$ & $\mathrm{T}$ & 203 & 26 & 28 & 48.1 & 51.9 \\
\hline 2024 & $\mathrm{~T}$ & G & 222 & 29 & 37 & 43.9 & 56.1 \\
\hline 2047 & A & G & 222 & 36 & 36 & 50.0 & 50.0 \\
\hline 2062 & G & A & 222 & 31 & 34 & 47.7 & 52.3 \\
\hline 2074 & $\mathrm{~T}$ & $\mathrm{C}$ & 222 & 35 & 37 & 48.6 & 51.4 \\
\hline 2092 & $\mathrm{C}$ & $\mathrm{T}$ & 222 & 32 & 41 & 43.8 & 56.2 \\
\hline 2125 & $\mathrm{~T}$ & $\mathrm{C}$ & 222 & 46 & 44 & 51.1 & 48.9 \\
\hline 2161 & G & A & 222 & 51 & 41 & 55.4 & 44.6 \\
\hline 2170 & G & A & 222 & 49 & 46 & 51.6 & 48.4 \\
\hline 2239 & $\mathrm{~T}$ & $\mathrm{C}$ & 222 & 36 & 31 & 53.7 & 46.3 \\
\hline 2248 & A & G & 222 & 33 & 29 & 53.2 & 46.8 \\
\hline 2251 & $\mathrm{C}$ & $\mathrm{T}$ & 222 & 33 & 30 & 52.4 & 47.6 \\
\hline 2266 & A & G & 222 & 31 & 32 & 49.2 & 50.8 \\
\hline 2449 & $\mathrm{C}$ & $\mathrm{T}$ & 123 & 49 & 19 & 72.1 & 27.9 \\
\hline
\end{tabular}

a Sequence of the assembled contig; ${ }^{b}$ Alternative sequence observed in RNA-seq reads; ${ }^{c}$ Phred-scaled quality score for the assertion made in Alt by BCFtools. 


\title{
Supplementary Fig. S1
}

\author{
Multiple alignment of the amino acid sequences of the RdRp regions of ObRV1 and related viruses
}

ObRV1:ASL68496.1:1274-1651 HarVA:YP_004376201.1:1274-1651 YP 006905850.1:1274-1651 DiV̄B:YP 006905848.1:1274-1651 CVA:ANE $\overline{0} 6570.1: 1246-1621$ CVA:APG53775.1:1246-1621 PCMV:YP_001497153.1:1748-2123 ApLV:ADT̄91605.1:1791-2166 NeLV:YP 009174681.1:1486-1861 NSV:YP $842438.1: 1484-1859$ CTLaV: $\bar{A} H J 80270.1: 1639-2014$ CTLaV:AHJ80314.1:1641-2016 CNRMV:ALP45953.1:1640-2015 CRMaV:AHA59466.2:1631-2006 CRMaV:AHJ80324.1:1628-2003 CRMaV:AKN20442.1:1631-2006 CGRMV:AFU54620.1:1628-2003 BanMMV:NP_112029.1:1372-1747

ObRV1:ASL68496.1:1274-1651 HarVA:YP 004376201.1:1274-1651 YP 006905850.1:1274-1651 DiV̄B:YP_006905848.1:1274-1651 CVA:ANE $06570.1: 1246-1621$ CVA:APG53775.1:1246-1621 PCMV:YP_001497153.1:1748-2123 ApLV: ADT̄91605.1:1791-2166 NeLV:YP_009174681.1:1486-1861 NSV:YP_842438.1:1484-1859 CTLaV:ĀHJ80270.1:1639-2014 CTLaV:AHJ80314.1:1641-2016 CNRMV:ALP45953.1:1640-2015 CRMaV: AHA59466.2:1631-2006 CRMaV:AHJ80324.1:1628-2003 CRMaV:AKN20442.1:1631-2006 CGRMV:AFU54620.1:1628-2003 BanMMV:NP_112029.1:1372-1747

ObRV1:ASL68496.1:1274-1651 HarVA:YP_004376201.1:1274-1651 YP_006905850.1:1274-1651 DiV̄B:YP_006905848.1:1274-1651 CVA:ANE0̄6570.1:1246-1621 CVA:APG53775.1:1246-1621 PCMV:YP_001497153.1:1748-2123 ApLV:ADT̄91605.1:1791-2166 NeLV:YP_009174681.1:1486-1861 NSV:YP 842438.1:1484-1859 CTLaV: $\bar{A} H J 80270.1: 1639-2014$ CTLaV:AHJ80314.1:1641-2016 CNRMV :ALP45953.1:1640-2015 CRMaV:AHA59466.2:1631-2006 CRMaV:AHJ80324.1:1628-2003 CRMaV:AKN20442.1:1631-2006 CGRMV:AFU54620 1:1628-2003 BanMMV:NP_112029.1:1372-1747

ObRV1:ASL68496.1:1274-1651 HarVA:YP_004376201.1:1274-1651 YP 006905850.1:1274-1651 DiV̄B:YP 006905848.1:1274-1651 CVA:ANE $\overline{06570.1: 1246-1621}$ CVA:APG53775.1:1246-1621 PCMV:YP_001497153.1:1748-2123 ApLV:ADT91605.1:1791-2166 NeLV:YP 009174681.1:1486-1861 NSV:YP_842438.1:1484-1859 CTLaV:ĀHJ80270.1:1639-2014 CTLaV:AHJ80314.1:1641-2016 CNRMV:ALP45953.1:1640-2015 CRMaV:AHA59466.2:1631-2006 CRMaV:AHJ80324.1:1628-2003 CRMaV:AKN20442.1:1631-2006 CGRMV:AFU54620.1:1628-2003 BanMMV:NP_112029.1:1372-1747
PKHSNGDSLTFFAAVKKRLKFSSPQIEREKFEKVRHLGSEMFELLLEKIPLDNKNDDLMMQICVNEYIERKVSKPAGTIK PKHSNQDSLTFFAAVKKRLKFSSPHVEREKFEKVRHLGSEMFDVFLSKINLDNSYNHELMOMSVNEYIEKKVSKTSNTIK PKHQNSDSLTFLAAVKKRLKFSSPSVERERFEKVRHLGNEMLDIFLDKIKIDNKLNSEMMARSYNEYVLKKVSKTANTIA PKHSNSDTLTFFAAVKKRLKFSSPQIEREKFEKVRHLGQEMLELFLEKVKVSNHYDKOMELMSYNEYIEKKVAKTGNTIA PRHFANDDLTFWSAVKKRLVFKNPLNNVHDFEKAKPFGKEMLDIFLKKVPL IPSFDQRMYEESISEFEEKKISKNAAMIG PRHFANDDLTFWSAVKRRLVFKNPLSNAHDFEKAKPFGKELLNIFLRKVPLKPNFDQRMYDESVSEFEEKKISKNAAMIG PRHKGTDSVTFLMAVKKRLSFSQPSIESAKLRRAMPFGKFLLQTFLKYIPLCGKHDSDLMSKAVNDFEEKKLSKSAATIE PRHKGTDTATFLMAVKKRLSFSSPAAEHAKLRRARPFGKFLLDTFLKRIPLNCRHDCEMMSSAVHAFEEKKLSKSMATIE PRHKGDDTATFLMAVKKRLRFSKPAQEVAKFRAAEPFGEYMLGVFLKHIKLNKNHEPQKMADAKREFEEKKTSKSAAVIE PRHKGDDTATFLMAVKKRLRFSKPAOETAKFRAAEPFGEYMLGIFLKHIKLNKNHEPLKMAAAKREFEEKKTSKSAAVIE PRHKAGDTATFVMAARKRLKFSRPANEROKFLSAIPYGDTMLRVFLEKVKLKPNFDHRLFEEARNDFEEKKLOKSMATLE PRHRAGDTATFVMAARKRLKFSLPANEQQKFLSAIPYGDTMLKVFLNKVKLKPNFDYRLFEEARNDFEEKKLQKSMATLE PRHKSGDTATFLMAARKRLKFSFPANERQKYLAAIPYGDTMLKVFLEKVKLKPAFDHLLFDEARNDFEEKKLGKSMATLE PRHKAGDTATFVMAARKRLKFSYPAREROKFMAAIPYGASMLOVFLKRVRLOPNFDHKLFEESRSDFEEKKLOKSMATLE PRHKAGDTATFVMAARKRLKFSFPARERQKYMAAIPYGESMLQVFLKRVKLQPNFDHRLFEESRADFEEKKLQKSMATLE PRHKAGDTATFVMAARKRLKFSFPAREKOKYLSAIPYGESMLOVFLKRVKLNSNFDYNLFEEARDDFEEKKLOKSMATLE PRHKAGDTATFVMAARKRLKFSIPAKEGQKFRAAIPYGESMLQIFLKKVKVQPNFDHKLFAEAVSDFEEKKLTKSMATLE PRHRNSDTVTFLMAVKKRLSFSQPRKEMQRYLMNKRKGEEMADAFEKFVPIKSNFSREKFIEAKMEFESKKLEKSKATIE

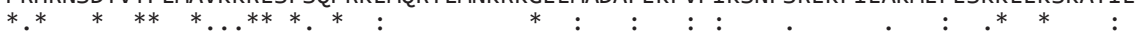
SHSGRSDCDWKLNDVFLFIKTQLCTKYEKRFSDAKAGQTLACFSHVILNRFAAPARYIEKKLSLCLPDNYYIHQKKNFDM SHSSRSEPDWKLNDVFLFMKTOLCTKYEKRFCDAKAGQTLACFSHIVLNRFAAPTRYIEKKISOCLPSNYYIHOKKNFDC SHSSRSEPDWKLNEIFLFMKTOLCTKFEKRFSDAKAGQTLACFSHIILNRFAAPTRYVEKKISEGL GKNFYIHOKKNFDV AHSNRSEPDWNLNEIFLFMKTQLCTKYEKRFCEAKAGQTLACFSHIVLNRFAGPTRYIEKKISSYLPNNYYIHQKKNFDK AHHDRSTTDWPINEIFLFIKSQLCTKKEKMFCDAKAGQTLACFSHLILCKFAPLNRYIEKKVTQCLPGNFYIHQKKNFDE AHHDRSTTDWPTNEIFLFIKSQLCTKKEKMFCDAKAGQTLACFSHLILCKFAPLNRYIEKKVTQSLPGNFYIHQKKNFDE NHSGRSSRDWPVDKALIFMKSQLCTKFDNRFRSAKAGQTLACFQHSVLCRFAPYMRYIEAKLFNALPDRFYIHSGKNIDD NHSGRSCEDWPVDKALIFMKSOLCTKFDNRFRSAKAGQTLACFOHSVLCRFAPYMRYIESKVVEALPSNLYIHSGKNIEE NHSGRSCRDWLIDLGFLFIKNOLCTKFEKRFADAKAAOTILCFOHEVLCRFAPYVRYIEKKLNDALPAKYYIHSGKNIDD NHSGRSCRDWLIDLGFLFIKNQLCTKFEKRFADAKAAQTILCFQHEVLCRFAPYVRYIEKKLNDALPAKYYIHSGKNIDD NHSGRSDPDWEVEKALIFMKSQLCTKFDNRFRDAKAGQTLACFHHNVLCRLAPYIRYIEKKVFAALPKNLYIHSGKNFDD NHSGRSDPDWEVEKALIFMKSQLCTKFDNRFRDAKAGQTLACFHHNVLCRLAPYIRYIEKKVFNSLPKNLYIHSGKNFDD NHSGRSDPDWEVEKALIFMKSOLCTKFDNRYRDAKAGQTLACFHHNVLCRLAPYVRYIEKKVFKALPRNLYIHSGKNFDD NHSGRSDPDWSIEKALIFMKSOLCTKFDNRFRSAKAGOTLACFHHDVLCRLAPYIRYIEKKVFKALPKNLYIHSARNFDD NHSGRSDPDWGVEKALIFMKSOLCTKFDNRFRNAKAGOTLACFHHDVLCRLAPYIRYIEKKVFKALPSNLYIHSARNFDD NHSGRSDPDWNVENASIFMKSQLCTKFDNRFRDAKAGQTLACFHHNVLCRLAPYIRYIEKKVFKALPKNLYIHSGKNFDD NHSGRSDPDWEKERALIFMKSQLCTKFDNRFRAAKAGQTLACFHHNVLCRLAPYIRYIEKKIFSHLPKNYYIHSGKNFDE NHAQRSNREWKIDEAMIFMKSQLCTKFEKRFVEAKAGQTLACFSHIVLCRFAPYVRYMEKIVNENLPKNFYIHNGKNFDD LNAWVVRNDFSDECLESDYEAFDSSQDCLILAFEYELLKYMGWSQSLLDDYLDLKFNLGCRLGNLAVMRFTGEFGTFLFN LNEWVIRNDFSESCLESDYEAFDSSQDCLILAFEYELLKYMGWKQDLLDDYLDLKFNLGCRLGNLAVMRFTGEFGTFLFN
LNDWVVANNFDSYCLESDYEAFDSSODCLILAFEYELLKYLGWDOSLLDDYLDLKFNLGCRLGNLAVMRFTGEFGTFLFN LNEWVIENKFTGESLESDYEAFDSSODCIILAFEYELLSYLGWNOSLLDDYLTIKFNLGCRLGNLAVMRFTGEFGTFLFN LEKWVKSYDFSGVCTESDYEAYDASQDSYTLAFEYELMKYLGVSNSMIEDYLYLKMHLNCKLGNLAIMRFTGEFCTFLFN LEKWVKSYNFNGVCTESDYEAYDASODSYTLAFEYELLRYLGVSNSL IEDYLYLKMHLNCKLGNLAIMRFTGEFCTFLFN LGNWVKKQNFSGECTESDYEAFDASQDHFILAFEIEIMRHLGLPEGLINDYIFIKCNLGSKLGSFAIMRFTGEASTFLFN LADWVKVNKFNGVCTESDYEAFDASQDHFILAFELEVMKHLGLPADLIADYTFIKTHLGSKLGNFAIMRFTGEASTFLFN LNDWVKDNDFSGICTESDYEAFDASQDHYIMAFEVAIMKYLGLPRDLINDYIFIKTHLGSKLGSFAIMRFSGEASTFLFN LNDWVKANNFSGVCTESDYEAFDASQDHYIMAFEVAVMKYLGLPRDLVNDYIFIKTHLGSKLGSFAIMRFSGEASTFLFN LRDWVIAHRFSGVCTESDYEAFDSSQDANILAFEVSLMNYLNLPRDLIEDYKHLKFNTHSKLGQFAVMRFTGEAGTFLFN LRDWVIKSNFSGMCTESDYEAFDSSODANILAFEVSLMNYLNLPRDL IEDYKHLKFNTHSKLGOFAVMRFTGEAGTFLFN LQEWVIQNNFVGTCTESDYEAFDSSQDANILAFEVSLMNYLNLPRDLIEDYKHLKFNTHSKLGRFAVMRFTGEAGTFLFN LRDWVIENNFTGVCTESDYEAFDSSQDANILAFEVSLMEYLRLPRDLIEDYKYLKFHTHSKLGQFAVMRFTGEAGTFLFN LRDWVIRNNFTGVCTESDYEAFDSSQDANILAFEVSLMEYLRLPRDLIEDYKYLKFHTHSKLGQFAVMRFTGEAGTFLFN LRDWVIANNFTGLCTESDYEAFDSSQDANILAFEVSLMTYLKLPRDLIEDYKHLKFHTKSKLGQFAVMRFTGEAGTFLFN LRDWVLKNSFIGMCTESDYXAFDSSQDSNILAFEVSLMRYLRLPRDLIEDYKYLKFNTRSKLGQFAVMRFTGEAGTSLFN LNDYVKKNNFSGRCIESDYEAFDASQDSQILAFEVAIMRRMNMPQEFIDDYVWLKCNLRSKLGNMAIMRFTGEAATFLFN

TLANMVFTFMSYDLTGKEAICFAGDDMCCNKGIRRRTDGRFDHILNRLSLKAKAVITTEPTFCGWRLTKYGIFKKPELVL TLANMVFTFMSYELNGKESICFAGDDMCCNKGIKKRIDGKFDHILKRLSLKAKAMITNEPTFCGWRLTPFGIYKKPELIL TLANMVFTFMTYDLNGTESICFAGDDMCCNRGIKARVDGKYDHILKRLTLKAKAVITKEPTFCGWRLTKYGIFKKPELVL TLANMTFTFMSYDLDDKEAICFAGDDMCCNKPVKKRSDGRYDHILKRLTLKAKVSYTREPTFCGWRLTKHGIFKKPELVL TLTNMLFTFMKYDVRKTHAICFAGDDMCANVRLPENLQ--HTNLLKKFSLKAKVDFTRSPTFCGWNLSRYGIVKKPELIA TLTNMLFTFMKYDVRKTHAICFAGDDMCANVRLPENHQ- -YSDLLKRSSLKAKVDFTRSPTFCGWNFSRYGIVKKPELIA TMANMLFTFLRYELSGHESISFAGDDMCANRRLRVRST - -YKSFLEKIRLKAKVQFTNFPTFCGWGLCPEGVFKKPDLVL TMANMLFTFLRYDLNGKEAICFAGDDMCANSRLKVTQT - -HSKFLDKIKLKAKVQFTITPTFCGWGLCEHGVFKKPDLVL TMSNMLFTFMKYEINGSESICFAGDDMCASKKLRLSDE - -HSSYLEKLRLKAKVCFTTRPTFCGWSLNRLGIFKKPOLVY TMSNMLFTFMKYEITGKESICFAGDDMCASKRLRLSTV--HSSYLEKLRLKAKVCFTSRPTFCGWSLNRLGIFKKPOLVY TLANMVFTFMRYETNGREAICFAGDDMCANKLLRRKSE - - FEHVLERMTLKAKVQHTSEPTFCGWRLGTFGIVKRPQLVQ TLANMVFTFMRYETNGRESICFAGDDMCANKLLRKRKE - -YEHVLERMTLKAKVQHTTEPTFCGWRLGPFGIIKRPQLVQ TLANMVFTFMRYETNGRESICFAGDDMCANKLLRKKGD- - FEHVLNRMTLKAKVOYTTEPTFCGWRLGSFGIVKRPOLVO TLANMVFTFMRYEVNGREAICFAGDDMCANKLLRKKSE - -FEHILERMTLKAKVQHTTEPTFCGWRLGNFGIIKRPQLVQ TLANMVFTFMRYEINGKEAICFAGDDMCANKLLRKKSE - -FEHILDRMTLKAKVOHTTEPTFCGWRLGNFGIVKRPOLVO TLANMVFTFMRYEVNGRESICFAGDDMCANKLLRKKSE - -FEHILERMTLKAKVOHTNEPTFCGWRLGNFGIIKRPOLVO TLANMVFTFMRYDLNGKEAICFAGDDMCANKRLRKKSE - - FEHILDRMTLKAKVQYTTEPTFCGWRLGDFGIVKRPQLVQ

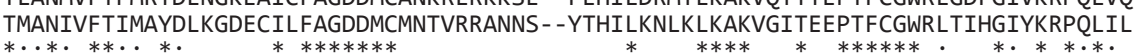


ObRV1:ASL68496.1:1274-1651 HarVA:YP_004376201.1:1274-1651 YP 006905850.1:1274-1651

DiV̄B:YP 006905848.1:1274-1651

CVA:ANE $\overline{0} 6570.1: 1246-1621$

CVA:APG53775.1:1246-1621

PCMV:YP_001497153.1:1748-2123

ApLV:ADT̄91605.1:1791-2166

NeLV:YP_009174681.1:1486-1861

NSV:YP $842438.1: 1484-1859$

CTLaV:ĀHJ80270.1:1639-2014

CTLaV:AHJ80314.1:1641-2016

CNRMV:ALP45953.1:1640-2015

CRMaV:AHJ80324.1:1628-2003

CRMaV:AKN20442.1:1631-2006

CGRMV:AFU54620.1:1628-2003

BanMMV:NP_112029.1:1372-1747
CRMaV:AHA59466.2:1631-2006

ERFLIAIEKNKLKDVIDSYYLECSYAYSLGERLFECFSEKDFVAHYCCIRLVHLHKDL

ERFLIAIEKGRLVDVIDSYYLECSYAYSLGERLSKCFSEKDFVAHYCCVRLVHKHKSL

ERFLIAIEKGRLLDVIDSYYIECSYAYNLGERLFECFSEKDFSAHYCCIRIVHKNKSL

ERFLIAMEKGRLKEVIDSYFIECSYAYNLGERLYECFSEKDFIAHYCCVRIVHENSSL

ARLAVAKOKGEVNLVLDSYFLEHLYAYNKGDHLFEILSEKELEHHYNLTRFFVKHGNL

ARLAVAKOKGEINLVIDSYFLEHLYAYNKGDHLFEILSEKELEHHYNLTRFFVKNSEL

ERLQIAVETNNLONCIDNYAIEVSYAYSMGESLSKYLSEEEMDAHYNCVRFIVKHSHL

ERLQIARETRNLENCIDNYAIEVSCAYRMGENLNLYLSPNEMDAHYNCVRFIILHNHL

ERMCIAIEKNNLQNCIDNYAIEVSYAYLMGENALVLMDEEEIHNHYMCVRTIVQNKNL

GRMCIAIEKNNLQNCIDNYAIEVSYAYLMGENALVLMDEEE IHNHYMCVRTIVQNKNL

ERILIALEKGNFNECIDNYAIEVSYAYNLGERLVSIMSEKELDAHYFCVRTFLOHKNL

ERILIALEKGNFNECIDNYAIEVSYAYNLGERLISIMSEKELDAHYFCVRTFLOHKNL

ERILIALEKGNFIECIDNYAIEVSYAYKLGERLISIMSEKELDAHYFCVRTFLONKKL

ERILIALEKGNFNECIDNYAIEVSYAYNLGERLISIMSEKELDAHYFCVRTFLONKKL

ERILIALEKGNFHECIDNYAIEVSYAYNLGERLISIMSEKELDAHYFCVRTFLQNKKL

ERILIALEKGNFHECIDNYAIEVSYAYNLGERLISIMSEKELDAHYFCVRTFLRNKNL

ERILIALEKGNFHECIDNYAIEVSYAYNLGERLISIMSEKELDAHYFCVRTFLONKCL

ERFMIAIENGNLENCIDNYAIECSYAYKLGDRLVSMFSEEENCAHYILVRYIVKKRHL

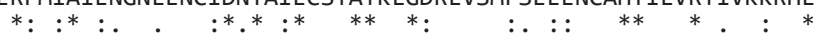

Asterisks $\left(^{*}\right)$, fully conserved residues; colons (:), residues with strongly similar properties; and periods (.), residues with weakly similar properties. See Table 2 for full names of viruses. 
Supplementary Fig. S2

Multiple alignment of the amino acid sequences of the RdRp regions of ObRV2 and related viruses

ObRV2:ASL68498.1:338-532 BCMV1:CEZ26300.1:295-487 FpMV4:YP_009272901.1:271-459 OMV3a:NP_660176.1:272-465 SSMV3:YP-009182164.1:264-461 MpMV3: AMM 45292.1:465-663 RSMV-17:ANRO2693.1:13-210 RSMV-15:ALD89120.1:432-629 RSMV-14:ALD89119, 1:461-658 HetMV1: AIF33766.2:356-558 COV:YP_005352912.1:336-529 BCMV3:YP_009182161.1:299-499 FpMV3:YP 009272900.1:297-5 SlaMV5:ALM62240.1:293-496 RSMV-19:ANRO2690.1:13-215 CDMV1: NP 660174.1:339-528 CPMV1:NP 660174.1:339-528 SsMV15: AHF48631.1:255-442 HFMV1:AIU44705.1:254-441 SsMV16:AHF48632.1:195-380 SSMV2:AHX84129.1:246-431 SlaMV3:ALM62243.1:252-438 OMV5: NP 660180.1:253-438 SlaMV2:ĀLM62242.1:235-420 FgMV1:YP 009126872.1:236-424 TbMV:AAZ $99833.1: 205-396$

ObRV2:ASL68498.1:338-532 BCMV1: CEZ26300.1:295-487 FpMV4:YP_009272901.1:271-459 OMV3a:NP_660176.1:272-465 SsMV3:YP-009182164.1:264-461 MpMV3:AMM̄45292.1:465-663 RSMV-17:ANR02693.1:13-210 RSMV-15:ALD89120.1:432-629 RSMV-14:ALD89119.1:461-658 HetMV1: AIF33766.2:356-558 COV:YP 005352912.1:336-529 BCMV3:ȲP_009182161.1:299-499 FPMV3:YP-009272900.1:297-500 SlaMV5:ALM62240.1:293-496 RSMV-19:ANRO2690.1:13-215 RSMV-19:ANRO2690.1:13-215 BSMV1:AHY03257.1:312-497 RCMV:AIT71973.1:289-475 SSMV15:AHF48631.1:255-442 SSMV15:AHF48631.1:255-442 SsMV16:AHF48632.1:195-380 SsMV2:AHX84129.1:246-431 SlaMV3:ALM62243.1:252-438 OMV5:NP_660180.1:253-438 SlaMV2: ĀLM62242.1:235-420 FgMV1:YP 009126872.1:236-424 TbMV: AAZ $\overline{9} 9833.1: 205-396$

ObRV2:ASL68498.1:338-532 BCMV1: CEZ26300.1:295-487 FpMV4:YP_009272901.1:271-459 OMV3a:NP 660176.1:272-465 SsMV3:YP-009182164.1:264-461 MpMV3 : AMM̄45292.1:465-663 RSMV-17:ANR02693.1:13-210 RSMV-15:ALD89120.1:432-629 RsMV-14:ALD89119.1:461-658 HetMV1:AIF33766.2:356-558 COV:YP 005352912.1:336-529 BCMV3:YY_009182161.1:299-499
FpMV3:YP-009272900.1:297-500 SlaMV5:ALLM62240.1:293-496 RSMV-19:ANR02690.1:13-215 BSMV1: AHY03257.1:312-497 CPMV1:NP 660174.1:339-528 RCMV:AIT71973.1:289-475 SCMV:AIT71973.1:289-475 SSMV15:AHF48631.1:255-442 SsMV16:AHF48632.1:195-380 SSMV16:AHF48632.1:195-380 SSMV2:AHX84129.1: 246-431
SlaMV3: ALM62243.1:252-438 OMV5:NP_660180.1:253-438 SlaMV2: $\bar{A} L M 62242.1: 235-420$ FgMV1:YP 009126872.1:236-424 TbMV:AAZ $99833.1: 205-396$
KVRVFAIPNPIFQRFLKPLHDWEMSVLKQLDTDGTYDQLRPLHRLKGKRV-- - - - - LYSFDLSAATDMFPKVLSAS KVRVFAMVDIWTQSILNPLHKKIFSIIRELPTDGTFDQLKPLDRLHELSTQD- - - - - RFSFDLSAATDRLPLALOKD KVRVFAITDVWTQSFLSPLHHAIFGFLKRIPMDGTFDQLKPLNALLSRGLKN- - - FYSYDLSAATDRLPITLQEQ KARVFAMADSITQSVMAPLNSWVFSKLKDLPMDGTFNQQAPLNRLVQLYQDGLLHDVE - -FYSYDLSSATDRLPMAFQKQ KARVFAITDSITQSVMGPISDAIFKMLRQIPMDGTFNOSAPLDRLVQLSKDGAIAEKDRIFYSYDLSAATDRLPINLOKD KVRVFAMVDAWTQWALYPIHELIFKILKDVPMDGTFDQTAPLKHVRPHSG- KVRVFAMVDAWTQWVLEPLHQYMFDILSHISMDGTFDQMRPVTAKAGTATA - - - - - AYSLDLTAATDRIPMELOER KVRVFAMADAWTOWVLEPFHQYLFDLLROIDMDGTFDQLRPVIKKLATVKA- - - - -AYSLDLTAATDRLPIAIOTV KVRVFAMVPTWFONLLRPLHDIIFEILSGVAODGTFNOMKPLKGHSSRFNM - . KVRVFAMVDPLTOWALRPIHKLLFLLLRYIPMDGTFDOLKPITRLLAOKPKV - - . - - LDSLDLSAATDRLPIAIOEW KVRVFAMVDPWSOMILRPFHLGLFKILRRIRMDGTFNQLKPLERAWGFKS - . K KVRVFALVDSITQSVMKPIHLGLFKVLRHLPNDGTFDQDASVTRCSEKASEAGK $-\cdots--0-0$ KIRFALVDSITQ

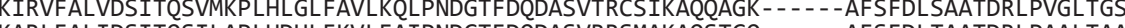
KARVVALTNWWIQCMFKPLHDEIFDKLRNISQDATFDQKGSTTNFIKVNRGKT-1-A KARIVAITNSWIQTAFYSLHLHVFKLLKNIDQDGTFDQERPFKLLIKWLNEPTQK-- - FYGFDLTAATDRLPIDLQVD KARVVGITDAWTQMLFKPLHDEIYAKLGKIPEDGTRDQLAPVKLLLSNLKNPY-- - - AVSVDLSAATDRLPVELQAR KCRPFAIFDYWSQLTLTPLHDWIYNQLRNIPNDCTFDQHKGVDKMNQIRSRKW----FYSYDLKSATDRFPVLLQER KSRVFAIFDYWSQTTLTPLHDWAFSTLRKIPQDCTFNQQEGVEKILRLKTRKH- - - - -YYSYDLKSATDRFPARFQRK KSRPFAIMDYWSQSALTPIHDLLYKLLGEIPEDCTFDQQKGVELMSRFPKSK-- - - - LFSLDLKSATDRFPVELQRR KSRPFAIVDYITOSALTPLHDRLYRVLKSIPODCTFDONKGFKDLLYGGGP - $\ldots$ KSRIIAVFDYWSQTALLPLHNSLIAFLKKIHNDCTFHQGKISSLMVTFKV- $\cdots \cdots$ FMCYDLTAATDRFPVQLQTA KMRVIAMVDYHSOFVLKKIHNSLFNKLKLIKSDRTFTQDPIFTTPTMGHR- - - - - FWSMDLSAATDRFPIDLOER KLRIVAIVDYYTQLFLKPIHEKIMNKLONLPCDRTYTQSPLNNWKDDGNM- - - - FWSIDLSSATDRFPISLORR KRRIIAMVDYHSOLALRKIHNGLLKLLTTLKCDRTFTQDPKHNWILDNNES - - - - FHSLDLSSATDRFPVKLQAR KRRIIAMVDYHSQLVLRSIHDGLLNKLRNLPQDRTYNQDPNNAWEENKEC - - $\ldots$ - FHSLDLSSATDRFPVKLQSR $* *:$ :***:*

MLSGLFG-DEF - GAAWYDMMSNTAFRSPERLSSP - - LKARVYRFTRGOPLGFYSSWPTFSLTHHMVVWLAAWRVYP - - - G ILTLLVS-PSF -AEAWGTALTGRPYKLKFG - - - - - TTEDELMYAVGOPMGALSSWGMLALTHHTIVOVAASRAGY - - - K ILSRLFG-ESF-AKAWKGLLVERPWY--..- - - - HKGIPYLYSVGQPMGALSSWGMLALTHHMIVQVAASRVGH- - - R IISVLFG-SKF-AKDWATLLVGRDWY--- - - - - LKDIPYRYSVGQPMGALSSWAMLALSHHVIVQIAAMRVG-- - $\mathrm{K}$ ILSIYCG-ESF-ASKWSILMTDRDWYLT-- - - - - -KEKRNLRYSVGQPMGALSSWAMLALTHHFIVGMAANRVG- - - -K LIGAILG-RES-AAAWANLLTGRTYALRTEDHNGN-ETVIKLTYAVGQPMGALSSWASLALTHHFLVQCAAWSAGFPK-W LVANLVN-SEF-AANWKTLLVGRKYVAFSPKR - - -GVSAELTYGVGQPMGALSSWSSLAITHHYMVQVSAWLAGVTPKG LFKHLVS-EEF - SVOWMRILVGRGYMAFSSKY - - - NVFKLLEYAVGOPMGALSSWASLAITHHFIVOCAAWEAGICPVG LMSOLIG-LDL-ATSWANLLTKIEYSINSMKF----NTYEKVKYTVGOPMGALSSWAMLALTHHLLVQISAWRVGAEKEG IISKIFT -PSI - GKAWTTLLVGRDYRVPKRDGQTT -VLPKSVTYAVGQPMGALSSWAMLAITHHFIVQIAAWQSGVTKYG LIQQLFKLTNAEAEAWRSLLVDRPYYCP-- - - - PLNTSVMYSVGQPMGALSSWAMLAMTHHLIVQVAAWRSGFDK -K ILSKIFS-DEF-GTSWKQLMVNRDFFFSLTNQKDY-GAPESLRYSVGQPMGALSSWPALALTHHWILQYCSNILGR--- T IIESLFKIPGL-SQSWQKVMVDRNFRFPLNIIENYDIEDIDYRYSVGQPMGCLSSWAGLAITHHWIMQLCSYLVTDS--W IIESLFQITDL - SNSWKSVMVDREFSFNDKIIKEFPELLKSYRYSVGQPMGCLSSWAGLAITHHWIMQYCSFLLKGN- -W ILESLTG-RPI-GESWLOMMTNRNFWFNGDKATKLGISAGPYOYAVGQPMGGLSSWAGLAITHHWIVOIAALOANKG- - N ILESLTG-RPI-GESWLQMMTNRNFWFNGDKATKLGISAGPYQYAVGQPMGGLSSWAGLAITHHWIVQIAALQANKG- -N ILSLL-- - GVRGDLWSQIISNINWH--.-1 I ILNCL---GLPGDTWREILA-RPYE------YMDREYVYAVGQPMGAYSSFAMLALTNHLIMYAAANKLGLVV-V

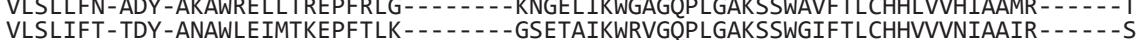
VLSLIFT-TDY-ANAWLEIMTKEPFTLK-----GSETAIKWRVGQPLGAKSSWGIFTLCHHVWNIAAIR-- - -

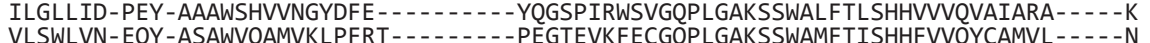
VLSWLVN-EQY-ASAWVQAMVKLPFRT- - - - PEGTEVKFECGQPLGAKSSWAMFTISHHFVVQYCAMVL- - - $-\mathrm{N}$ ILAELFG-SAF-ASAWKTILVEYSFHMK---- - - GKGDVL-YGAGQPMGAYSSWTVFALCHHIVVQYAASLAGY - - T LLSYLYG-SEI-SSAWKQLLIDRTYKT-- - - - PEGDELHYKVGQPMGAYSSWAAFTLTHHLVVFYSARMAG--- - I LLEIAIS-KEV-ADGWNHILSTRKFET-----PEGNLISYEVGQPMGSYSSWAAFTLTHHLVVHWCAKLNG--- I

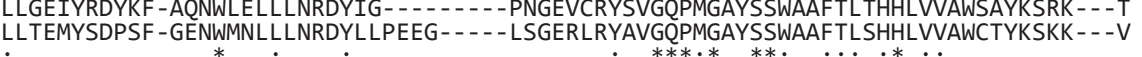

KKFWDYALLGDDIVIADEAVALEYRDIMQQ-MGGVINMTKSLISHNGC-CEFAK DLFLDYALLGDDICIANKAVADNYLLIMRD-LGVEINLSKSLISSTGV-VEFAK TMFRDYALLGDDICIADSAVAKSYLSLMTD-YGVDINLSKSLESDIGV-AEFAK LPFTNYALLGDDIVIADKAVATSYHMIMTOILGVEINLSKSLVSNNSF--EFAK LGFNHYALGDDIVIADKSVADSYYMIMTEILGVOINLSKSLVSTNSF--EFAK LGFNHYALLGDDIVIADKSVADSYYMIMTEILGVQINLSKSLVSTNSF- - EFAK
KLYTNYAVLGDDVVIGDRSVALAYLRIMKS-LGVGVNTSKSLLSHRGIAFEFAK EWFTDYAVLGDDLVIFNORVKVHYLKIVAA-MGVOCGAHKSLLSPRGVAIEFAK EWFTDYAVLGDDLVIFNQRVKVHYLKIVAA-MGVQCGAHKSLLSPRGVAIEFAK TWFTSYAVLGDDLVIFDQRVKVKYLAIVDA-LGVQCGIAKSLLSPTGTAIEFAK
TWFSDYAILGDDLVIFNYDVAHEYIKVIHK-IGMEIGLHKSVLSRKFTSLEFAK
KWFTAYALLGDDLTVGNRAVSNRYOLIMIKHLGVEVLAKSIISDKGIGLEFAK KWFTAYALLGDDL TVGNRAVSNRYQLIMIKHLGVEVGLAKSIISDKGIGLEFAK GWEENYEILGDIVIFDKKVAKYYHRVLTG-LGVECNLAKSIMSHRGIGLEFK DWEERYEILGDDIVIFDEELANTYLOVMEW-LGLDINLSKSIISKNKPTFEFAK NWEDRYEVLGDDIVIFDTLLANQYLEVMSH-LGLEINLSKSINASNTPVFEFAK SWYINYEVLGDDLVIFEADVAREYLKIMAD-LGTEINLTKSIOSPERPAFEFAK NKFSEYLVLGDDIVIANNEVADAYLVLMKT-LGVDINLSKSLISSQLL-EFAK NKFSEYLVLGDDIVIANNEVADAYLVLMKT-LGVDINLSKSLISSQLL- -EFAK TRFTDYCILGDDIVIAHDTVASEYLKLMET-LGLSISSGKSVISSEFT--EFAK KGSGLYAILGDDVAISRGDLATEYNKIMHL-LGVEINPIKGFTGKIL---EFAK NSPLDYVLLGDDIVIRGRALATEYKRIMFQ-LGVTISDAKTHVSKDTF--EFAK NDAYIIGDIVLRGRALATEYKRIMSN-LGVEISESKSHVSKDTF--EFAK ARPC IDNPRYKILGDDIVICDHALAAKYLEIMSQ-LGVEISPVKTHVSENLF--EFAK SWYSNYALLGDDLVIGDEDVGHHYKIVMLS-LGVLISSNKTHEGNLLC- - EFAK KDFTNYILLGDDIVINNDKVAKYYIRTMKR-LGVELSMNKTHVSKNTY--EFAK NNFSDYILLGDDIVIKNDKVAKTYMKWMNY - IGVELSESKTHVSKDTY- - EFAK MDFDQYIILGDDIVIKDNAIASIYRGQMMR-MGVDISIPKTHVSKDTY- -EFAK IRSSQYIILGDDIVIKDNDIARKYIGQMSK-LGVAISMQKTHVSKDTY--EFAK

Asterisks $\left(^{*}\right)$, fully conserved residues; colons (:), residues with strongly similar properties; and periods (.), residues with weakly similar properties. See Table 2 for virus names. 